\title{
Self-reported oral status and habits related to oral care in adult Poles: A questionnaire study
}

\section{Samoocena stanu jamy ustnej i nawyków związanych z opieką stomatologiczną dorosłych Polaków - badanie ankietowe}

\author{
Renata Górska ${ }^{A, E, F}$, Bartłomiej Górski ${ }^{B-D}$ \\ Department of Periodontology and Oral Diseases, Medical University of Warsaw, Poland \\ A - research concept and design; $\mathrm{B}$ - collection and/or assembly of data; $\mathrm{C}$ - data analysis and interpretation; \\ $\mathrm{D}$ - writing the article; $\mathrm{E}$ - critical revision of the article; $\mathrm{F}$ - final approval of the article
}

\author{
Address for correspondence \\ Bartłomiej Górski \\ E-mail:bartek_g3@tlen.pl \\ Funding sources \\ None declared \\ Conflict of interest \\ None declared \\ Acknowledgements \\ Authors would like to thank Prof. Elżbieta Dembowska, \\ Prof. Maria Chomyszyn-Gajewska, PhD Natalia Lewkowicz, \\ Prof. Tomasz Konopka, DDS Urszula Korzeniowska, \\ Prof. Aida Kusiak, DDS Ewa Maliszewska-Bukowińska, \\ PhD Zdzisława Sawkiewicz, PhD Beata Wierucka-Młynarczyk, \\ and DDS Patrycja Załęska for their help with the acquisition \\ of data.
}

Received on March 19, 2018

Reviewed on May 14, 2018

Accepted on May 28, 2018

DOI

10.17219/dmp/91774

Copyright

() 2018 by Wroclaw Medical University

and Polish Dental Society

This is an article distributed under the terms of the

Creative Commons Attribution Non-Commercial License

(http://creativecommons.org/licenses/by-nc-nd/4.0/)

\begin{abstract}
Background. Bacterial plaque control plays a key role in the prevention of caries and periodontal diseases. Hygiene negligence in this respect may influence the state of gingiva, and - in the long term - the number of lost teeth. The recommended method of mechanical control of dental plaque is tooth brushing twice a day.

Objectives. The aim of the study was to assess the frequency of tooth brushing, the use of various oral hygiene accessories, the number of preserved teeth, and the occurrence of gingival bleeding in adult Poles, based on a questionnaire study.

Material and methods. The prepared questionnaire consisted of a general part, assessing the socioeconomic and general medical status of respondents, as well as of specific questions about behavioral actions related to oral hygiene. The study was conducted in 10 Polish cities in Mobile Medical Units as part of the "Health First" campaign in 2017.
\end{abstract}

Results. The study included 713 respondents: 447 females and 264 males at an average age of $51.1 \pm 17.6$ years. During the previous 6 months, 448 females and 265 males had visited the dentist. The average number of teeth among the respondents aged $35-44$ years was 27 , and for subjects $>65$ years old -13 . There were statistically significant differences in the frequency of tooth brushing depending on sex and place of residence. The respondents used manual soft and medium toothbrushes more often than electric brushes $(p<0.05)$. Inhabitants of larger cities, compared to rural residents, used dental floss and toothpicks more frequently $(p<0.05)$. In total, $271(50 \%)$ of the respondents reported gingival bleeding during tooth brushing. There was a statistically significant association of gingival bleeding with genetic load, and with the use of a manual soft toothbrush and mouthwash.

Conclusions. Pro-health behaviors of adult Poles in maintaining optimal oral hygiene are unsatisfactory and need improvement.

Key words: dental prophylaxis, gingivitis, dental plaque, toothbrush

Słowa kluczowe: profilaktyka stomatologiczna, zapalenie dziąseł, płytka nazębna, szczoteczka do zębów 


\section{Introduction}

Bacteria present in the oral cavity are characterized by the formation of biofilms. ${ }^{1}$ Natural accumulation of supragingival plaque on tooth surfaces is associated with the development of gingivitis. The symptoms of gingivitis include change in color, shape, consistency of gingiva, as well as bleeding while tooth brushing and eating hard foods. Bacterial plaque accumulation is also an etiological factor of dental caries. Regular, mechanical plaque control is, therefore, of fundamental importance in maintaining oral health and constitutes the basis in prevention of the most common oral cavity infections: caries and periodontal diseases.

Supragingival plaque should be removed mechanically by a regular use of a toothbrush at least twice a day. The effectiveness of this procedure depends on the type of toothbrush, brushing technique, patient's motivation, time and frequency of brushing. It should be remembered that the occurrence of supragingival plaque varies depending on the tooth surface and the position of the tooth in the arch. Studies have shown that plaque accumulation is greater on lingual surfaces of teeth and on molars in comparison with anterior teeth. ${ }^{2,3}$ Supragingival plaque is also more common on interproximal surfaces of teeth than on vestibular surfaces. In order to reduce the retention of plaque in interdental spaces, it is necessary to use daily additional accessories, such as dental floss and interdental brushes. Besides, mechanical control of bacterial plaque can be supplemented with the use of mouthwash, which - by means of chemical control - reduces the deposition of biofilm also on adhesive surfaces other than hard tissues of teeth, such as mucosal membrane. The use of antiseptics contributes to a greater reduction of plaque and gingivitis. ${ }^{4}$ On the other hand, the sole use of mouthwash is not an effective way to control bacterial biofilm. ${ }^{5}$ Implementation of various methods of maintaining optimal oral hygiene is particularly important in populations where an increased occurrence of oral infections is observed.

In the population of adult Poles, gingivitis is found in more than $98 \%$ of individuals, and almost $100 \%$ of subjects suffer from caries. ${ }^{6-8}$ Over $16 \%$ of Poles aged $35-44$ years and almost $20 \%$ of those aged $65-74$ years require comprehensive and advanced periodontal treatment, which indicates large limitations in the field of dental care. ${ }^{6,7}$ Unfavorable oral health situation occurs despite unlimited availability of various oral hygiene products present on the market. One should also take into account the importance of pro-health awareness of patients, the socio-economic and behavioral conditions, as well as raising their sense of co-responsibility for the state of their own health, which is particularly important in the case of social infectious diseases, such as caries and periodontal diseases.
The aim of the study was to assess the frequency of tooth brushing, the use of various oral hygiene accessories, the number of preserved teeth, and the occurrence of gingival bleeding in adult Poles, based on a questionnaire study.

\section{Material and methods}

The study was conducted in 10 Polish cities in Mobile Medical Units as a part of the "Health First" campaign in 2017. The campaign accompanied the "Summer with the Radio" route of the First Channel of the Polish Radio. Patients who approached the medical stand were asked to fill in an anonymous questionnaire. Those who completed the questionnaire form agreed to the obtained data being processed by signing the appropriate statement.

In addition to a general part, concerning gender, age, place of residence (village / medium-sized city / big city), education (primary / secondary / undergraduate / higher), height, weight, diabetes, and number of teeth present in the oral cavity, 6 additional questions were included in the questionnaire. The respondents were asked to provide information on smoking (current / in the past / never; the number of cigarettes smoked per day during the addiction period), genetic load of periodontitis (early loss of teeth in parents or siblings), date of the last visit to the dentist (visit in the last 6 months / more than 6 months, but not more than 12 months ago / over 1 year ago / over 2 years ago), frequency of tooth brushing during the day (0 times a day / once a day / twice a day / 3 times a day / 4 times a day), use of various instruments for oral hygiene (electric toothbrush / sound or sonic brush / manual toothbrush with soft bristles / manual toothbrush with medium bristles / manual toothbrush with hard bristles / interdental or monotip brush / dental floss / toothpick / tongue cleaner / irrigator / mouthwash), and occurrence of gingival bleeding during tooth brushing (never / less than once a week / once every few days / always).

All statistical analyses were performed with the STATISTICA 13 program (StatSoft Polska Sp. z o.o., Kraków, Poland). In order to compare the mean number of teeth between 2 (sex) or more groups (place of residence, education), comparisons were made using the t-test or the analysis of variance (ANOVA). The association between age and number of teeth was evaluated based on the regression analysis, using polynomial functions. The evaluation of the association between the frequency of tooth brushing and gender, age, place of residence, or education was performed using the $\chi^{2}$ test. The assessment of the relationship between the occurrence of bleeding from gingiva and other factors was performed using the correlation analysis. For all the analyses, the significance level was assumed at $\mathrm{p}<0.05$. 


\section{Results}

The study included 713 subjects: 448 females and 265 males. In the case of 2 questionnaires, there was no data regarding sex. The average age was $51.1 \pm 17.6$ years $(51.1 \pm 17.4$ years for women, $51.0 \pm 17.8$ years for men). The characteristics of the study group are shown in Table 1. Body mass index (BMI) was calculated by dividing body weight (in $\mathrm{kg}$ ) by height (in $\mathrm{m}^{2}$ ). Overweight was diagnosed in the case of BMI of $25-29.9 \mathrm{~kg} / \mathrm{m}^{2}$, and obesity at BMI $\geq 30 \mathrm{~kg} / \mathrm{m}^{2}$. There were statistically significant differences between the genders regarding the last visit to the dentist $(\mathrm{p}=0.009)$. During the last 6 months, 265 (59.2\%) females and 135 (50.9\%) males visited the dental office, while 49 (10.9\%) females and 50 (18.9\%) males were treated earlier than 24 months ago.

No statistically significant differences were observed between the average number of teeth for each sex, as well as for place of residence (Table 2). However, there were significant differences regarding education. Changes in

Table 1. Characteristics of the study group

\begin{tabular}{|c|c|c|}
\hline Parameter & Variable & n (\%) \\
\hline Sex & $\begin{array}{l}\text { female } \\
\text { male }\end{array}$ & $\begin{array}{l}448(62.8) \\
265(37.2)\end{array}$ \\
\hline Age [years] & $\begin{array}{c}\leq 20 \\
21-34 \\
35-44 \\
45-65 \\
>65\end{array}$ & $\begin{array}{c}37(5) \\
98(14) \\
121(17) \\
296(42) \\
159(22)\end{array}$ \\
\hline Place of residence & $\begin{array}{l}\text { village } \\
\text { medium-sized city } \\
\text { big city }\end{array}$ & $\begin{array}{r}86(12.3) \\
383(54.9) \\
229(32.8)\end{array}$ \\
\hline Education & $\begin{array}{c}\text { primary } \\
\text { secondary } \\
\text { undergraduate } \\
\text { higher }\end{array}$ & $\begin{array}{c}82(12.2) \\
313(46.6) \\
41(6.1) \\
235(35.0)\end{array}$ \\
\hline BMI $\left[\mathrm{kg} / \mathrm{m}^{2}\right]$ & $\begin{array}{l}<18.5 \text { (underweight) } \\
18.5-24.99 \text { (normal) } \\
\geq 25 \text { (overweight) }\end{array}$ & $\begin{array}{r}26(3.85) \\
258(38.3) \\
390(57.9)\end{array}$ \\
\hline Nicotinism & $\begin{array}{l}\text { current } \\
\text { in the past } \\
\text { never }\end{array}$ & $\begin{array}{r}84(13.5) \\
120(19.3) \\
419(67.2)\end{array}$ \\
\hline Diabetes & $\begin{array}{l}\text { type I } \\
\text { type II }\end{array}$ & $\begin{array}{l}21(3.0) \\
39(5.5)\end{array}$ \\
\hline $\begin{array}{l}\text { Number of teeth } \\
\text { depending on age }\end{array}$ & $\begin{array}{c}\leq 20 \text { years } \\
21-34 \text { years } \\
35-44 \text { years } \\
45-65 \text { years } \\
>65 \text { years }\end{array}$ & $\begin{array}{l}27.43 \\
29.47 \\
27.80 \\
21.04 \\
13.49\end{array}$ \\
\hline $\begin{array}{l}\text { Genetic } \\
\text { susceptibility } \\
\text { to periodontitis }\end{array}$ & $\begin{array}{l}\text { yes } \\
\text { no }\end{array}$ & $\begin{array}{l}136(20.7) \\
521(79.3)\end{array}$ \\
\hline $\begin{array}{l}\text { Last visit at dental } \\
\text { office }\end{array}$ & $\begin{array}{c}\leq 6 \text { months ago } \\
>6 \text { months and } \leq 12 \text { months ago } \\
>12 \text { months and } \leq 24 \text { months ago } \\
>24 \text { months ago }\end{array}$ & $\begin{array}{r}400(57.2) \\
116(16.6) \\
82(11.7) \\
101(14.4)\end{array}$ \\
\hline
\end{tabular}

BMI - body mass index. Data presented as number (percentage).
Table 2. Average number of teeth depending on sex, place of residence and education

\begin{tabular}{|c|c|c|c|c|c|}
\hline \multirow{2}{*}{$\begin{array}{c}\text { Age } \\
\text { [years] }\end{array}$} & \multicolumn{4}{|c|}{ Sex } & \multirow{2}{*}{$p$-value } \\
\hline & \multicolumn{2}{|c|}{ female } & \multicolumn{2}{|c|}{ male } & \\
\hline$\leq 20$ & \multicolumn{2}{|c|}{28.50} & \multicolumn{2}{|c|}{26.00} & 0.218 \\
\hline $21-34$ & \multicolumn{2}{|c|}{29.79} & \multicolumn{2}{|c|}{29.14} & 0.569 \\
\hline $35-44$ & \multicolumn{2}{|c|}{27.56} & \multicolumn{2}{|c|}{28.00} & 0.741 \\
\hline $45-65$ & \multicolumn{2}{|c|}{21.16} & \multicolumn{2}{|c|}{20.90} & 0.888 \\
\hline$>65$ & \multicolumn{2}{|c|}{13.00} & \multicolumn{2}{|c|}{13.91} & 0.762 \\
\hline General & \multicolumn{2}{|c|}{22.10} & \multicolumn{2}{|c|}{20.79} & $<0.001$ \\
\hline \multirow{2}{*}{$\begin{array}{l}\text { Age } \\
\text { [years] }\end{array}$} & \multicolumn{4}{|c|}{ Place of residence } & \multirow{2}{*}{$p$-value } \\
\hline & village & \multicolumn{2}{|c|}{ medium-sized city } & big city & \\
\hline$\leq 20$ & \multicolumn{2}{|l|}{28.00} & 28.00 & 27.00 & 0.911 \\
\hline $21-34$ & \multicolumn{2}{|l|}{26.50} & 29.75 & 29.93 & 0.152 \\
\hline $35-44$ & \multicolumn{2}{|l|}{28.00} & 27.63 & 27.89 & 0.977 \\
\hline $45-65$ & \multicolumn{2}{|l|}{20.94} & 20.08 & 22.09 & 0.627 \\
\hline$>65$ & \multicolumn{2}{|l|}{20.25} & 12.77 & 13.91 & 0.296 \\
\hline General & \multicolumn{2}{|l|}{22.35} & 19.47 & 23.47 & 0.024 \\
\hline Age & & & lucation & & \\
\hline [years] & primary & secondary & undergradua & higher & \\
\hline$\leq 20$ & 28.50 & 28.00 & - & - & 0.541 \\
\hline $21-34$ & 23.00 & 28.75 & - & 30.19 & 0.003 \\
\hline $35-44$ & 22.00 & 26.00 & 31.00 & 29.08 & 0.006 \\
\hline $45-65$ & 6.89 & 20.93 & 23.75 & 25.06 & $<0.001$ \\
\hline$>65$ & 10.80 & 16.24 & 16.00 & 12.78 & 0.458 \\
\hline General & 13.16 & 20.80 & 23.67 & 25.35 & $<0.001$ \\
\hline
\end{tabular}

the number of teeth depending on age, broken down by sex, place of residence and education, are shown graphically in diagrams (Fig. 1-4).

There were statistically significant differences in the frequency of tooth brushing during the day depending on sex and place of residence. Women, young adults (aged 21-34 years) living in large cities, with higher education brushed teeth more often than men, older people living in the countryside, with basic education (Table 3 ).

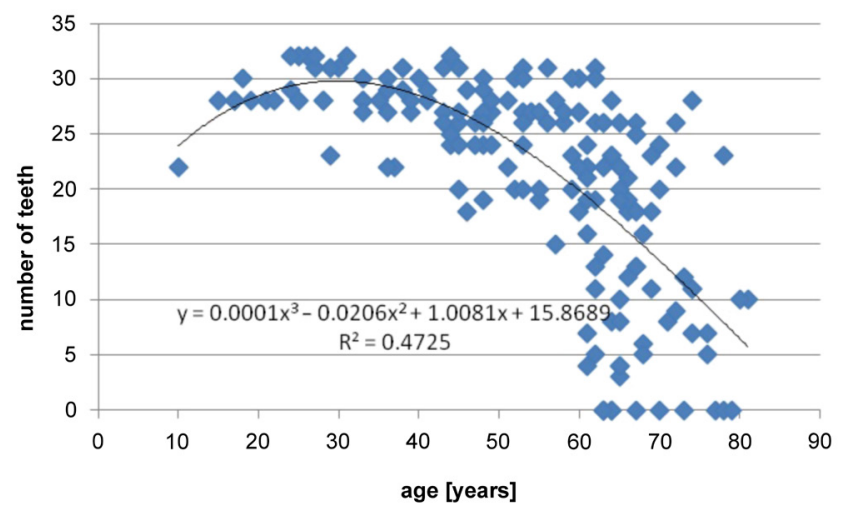

Fig. 1. Graph showing a change in the number of teeth for the whole group depending on age, with a matched regression function (3 ${ }^{\text {rd }}$ degree polynomial function) 


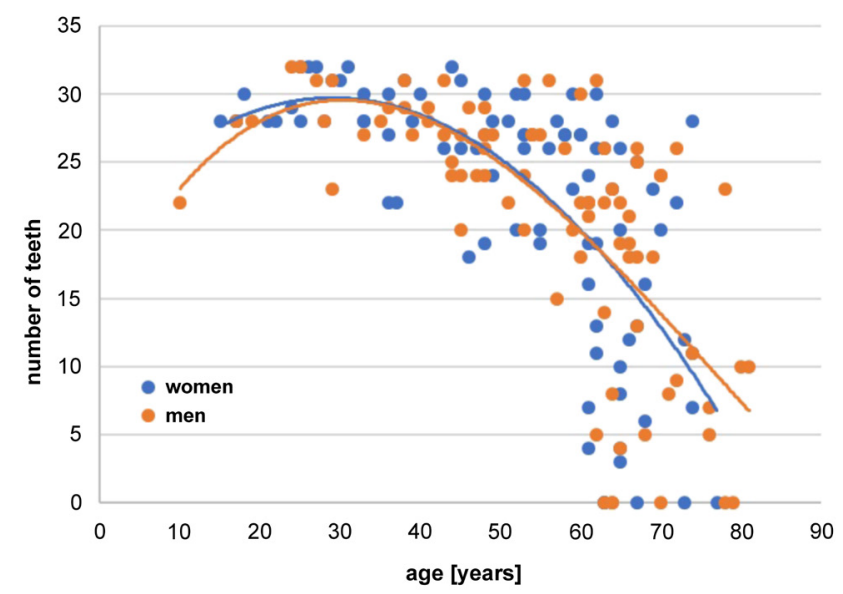

Fig. 2. Graph showing a change in the number of teeth for the whole group depending on age, broken down by sex, with a matched regression function ( $3^{\text {rd }}$ degree polynomial function)

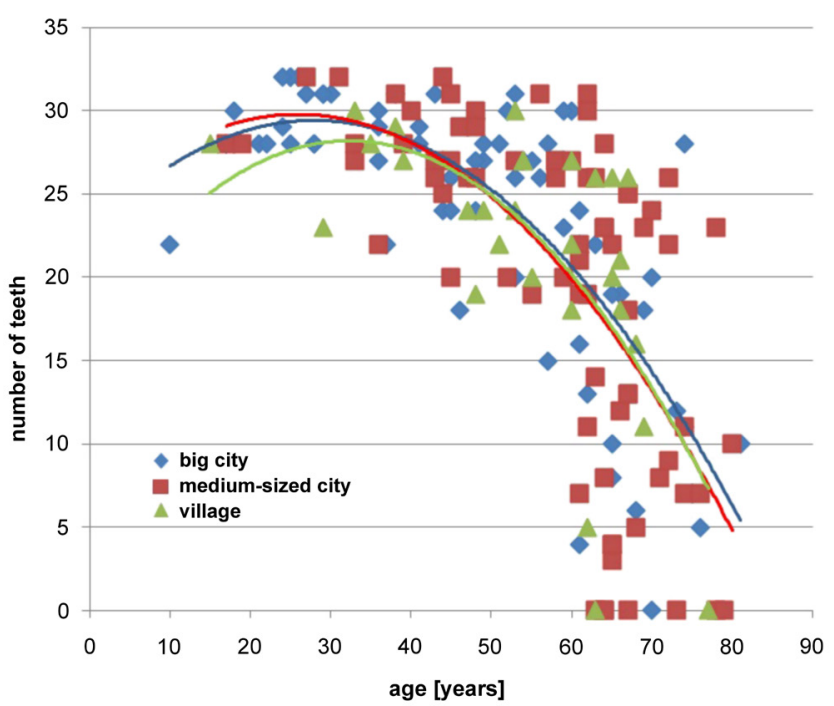

Fig. 3. Graph showing a change in the number of teeth for the whole group depending on age, broken down by place of residence, with a matched regression function ( $3^{\text {rd }}$ degree polynomial function)

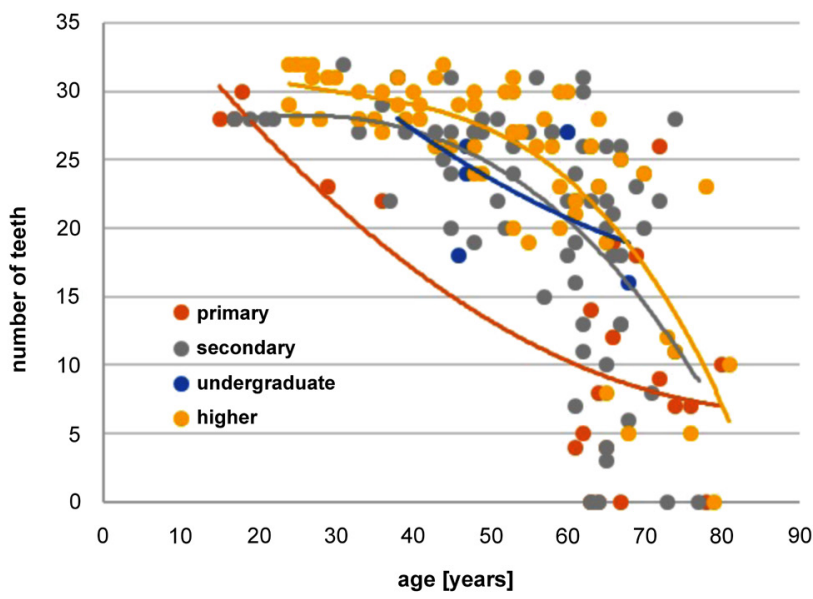

Fig. 4. Graph showing a change in the number of teeth for the whole group depending on age, broken down by education, with a matched regression function ( $3^{\text {rd }}$ degree polynomial function)
The frequency of using various oral hygiene devices is shown in Table 4 . There were no statistically significant differences between the frequency of using various types of toothbrushes with regard to gender and place of residence $(p>0.05)$. On the other hand, a statistically significant increase in the use of manual toothbrushes with soft and medium bristles was observed in comparison with electric brushes $(\mathrm{p}<0.05)$. Statistically significantly higher frequency of using dental floss, tongue cleaner and mouthwash was found for women compared to men $(\mathrm{p}<0.001)$. Inhabitants of larger cities compared to rural residents used dental floss and toothpicks more often $(\mathrm{p}<0.05)$.

Two hundred sixty-five (50\%) respondents never observed bleeding from gingiva while brushing their teeth, 192 (36\%) had bleeding less than once a week, 51 (9\%) had bleeding once every few days, while $28(5 \%)$ respondents noticed bleeding during every tooth brushing. A statistically significant positive association of gum bleeding with genetic load, and with the use of a manual brush with soft bristles and mouthwash was observed (Table 5). The chance of bleeding decreased with age, weight, BMI, and nicotinism $(\mathrm{p}<0.05)$.

\section{Discussion}

Evaluating pro-health behaviors within the scope of optimal oral hygiene maintenance is of great importance with regard to planning preventive programs and shaping the healthcare system. Periodontal diseases are conditions of complex etiology, but bacterial plaque remains the most important causative factor. The latest epidemiological studies of the periodontal status of adult Poles were conducted in 2012 (subjects aged 35-44 years) and in 2014 (subjects aged 65-74 years) ${ }^{6,7}$ Conducting such studies is associated with both economic and organizational problems. Therefore, questionnaires may be used to analyze basic data and to evaluate simple variables as interpreted by patients. The value of surveys in comparison with well-planned epidemiological studies is certainly lower, but absolutely justified, especially with reference to socio-demographic and behavioral factors. Nonetheless, the obtained data should still be evaluated cautiously. The results presented in this work were obtained due to surveys, which were filled out by 713 respondents as part of the "Health First" program. The Mobile Medical Unit was mainly approached by adult people ( $42 \%$ were aged $45-65$ years and $22 \%$ - over 65 years). The majority of respondents (62.9\%) were women, although men are more susceptible to periodontitis (due to addictions and reluctance to visit a dental office). Individuals who volunteered to take part in the survey were mostly residents of medium-sized cities, with higher or secondary education. Only $12 \%$ were people living in the countryside with primary education. In the study group, almost 58\% of the respondents were overweight or obese, almost 14\% smoked, and almost 9\% had diabetes. 
Table 3. Frequency of tooth brushing depending on sex, age, place of residence, and education

\begin{tabular}{|c|c|c|c|c|c|c|c|}
\hline & /ariahlo & & & cy of tooth b & ing & & onalus \\
\hline & & 0 times a day & once a day & twice a day & 3 times a day & 4 times a day & \\
\hline Sex & $\begin{array}{l}\text { female } \\
\text { male } \\
\text { general }\end{array}$ & $\begin{array}{r}17(3.8) \\
8(3.0) \\
25(3.5)\end{array}$ & $\begin{array}{r}54(12.1) \\
66(24.9) \\
120(16.9)\end{array}$ & $\begin{array}{l}252(56.3) \\
138(52.1) \\
390(54.7)\end{array}$ & $\begin{array}{r}78(17.4) \\
37(14.0) \\
115(16.1)\end{array}$ & $\begin{array}{l}47(10.5) \\
16(6.0) \\
63(8.8)\end{array}$ & $<0.001^{*}$ \\
\hline Age [years] & $\begin{array}{c}\leq 20 \\
21-34 \\
35-44 \\
45-65 \\
>65\end{array}$ & $\begin{array}{r}0(0.0) \\
1(1.0) \\
1(0.8) \\
11(3.7) \\
12(7.5)\end{array}$ & $\begin{array}{l}16(43.2) \\
10(10.2) \\
19(15.7) \\
46(15.5) \\
29(18.2)\end{array}$ & $\begin{array}{r}18(48.6) \\
57(58.2) \\
69(57.0) \\
171(57.8) \\
74(46.5)\end{array}$ & $\begin{array}{c}3(8.1) \\
21(21.4) \\
19(15.7) \\
44(14.9) \\
27(17.0)\end{array}$ & $\begin{aligned} & (0.0) \\
9 & (9.2) \\
13 & (10.7) \\
24 & (8.1) \\
17 & (10.7)\end{aligned}$ & $<0.001^{*}$ \\
\hline $\begin{array}{l}\text { Place } \\
\text { of residence }\end{array}$ & $\begin{array}{c}\text { village } \\
\text { medium-sized city } \\
\text { big city }\end{array}$ & $\begin{array}{r}6(7.0) \\
15(3.9) \\
2(0.9)\end{array}$ & $\begin{array}{l}20(23.3) \\
70(18.3) \\
28(12.2)\end{array}$ & $\begin{array}{r}48(55.8) \\
204(53.3) \\
129(56.3)\end{array}$ & $\begin{array}{c}7(8.1) \\
74(19.3) \\
32(14.0)\end{array}$ & $\begin{array}{c}5(5.8) \\
20(5.2) \\
38(16.0)\end{array}$ & $<0.001^{*}$ \\
\hline Education & $\begin{array}{c}\text { primary } \\
\text { secondary } \\
\text { undergraduate } \\
\text { higher }\end{array}$ & $\begin{array}{r}6(7.3) \\
11(3.5) \\
0(0.0) \\
3(1.3)\end{array}$ & $\begin{array}{c}29(35.4) \\
62(19.8) \\
6(14.6) \\
18(7.7)\end{array}$ & $\begin{array}{r}37(45.1) \\
167(53.4) \\
26(63.4) \\
136(57.9)\end{array}$ & $\begin{array}{c}7(8.5) \\
49(15.7) \\
5(12.2) \\
49(20.9)\end{array}$ & $\begin{array}{c}3(3.7) \\
24(7.7) \\
4(9.8) \\
29(12.3)\end{array}$ & $<0.001^{*}$ \\
\hline
\end{tabular}

* $p$-value based on the $\chi^{2}$ test, which indicated relationships between frequency of tooth brushing and other categorical traits.

Data presented as number (percentage).

Table 4. Frequency of use of various oral hygiene devices

\begin{tabular}{|c|c|c|c|c|}
\hline \multirow{2}{*}{ Device } & \multicolumn{4}{|c|}{ Frequency of use } \\
\hline & every day & once every few days & less than once a week & never \\
\hline Electric toothbrush & $102(22)$ & $23(5)$ & $24(5)$ & $321(68)$ \\
\hline Sound/sonic toothbrush & $15(4)$ & $4(1)$ & $8(2)$ & $400(4)$ \\
\hline Manual toothbrush with soft bristles & $178(38)$ & $13(3)$ & $23(5)$ & $253(54)$ \\
\hline Manual toothbrush with medium bristles & $344(62)$ & $25(5)$ & $33(6)$ & $149(27)$ \\
\hline Manual toothbrush with hard bristles & $49(12)$ & $5(1)$ & $13(53)$ & $332(83)$ \\
\hline Interdental/monotip brush & $26(6)$ & $6(1)$ & $20(5)$ & $370(88)$ \\
\hline Dental floss & $114(18)$ & $130(20)$ & $122(19)$ & $271(43)$ \\
\hline Toothpick & $103(17)$ & $100(16)$ & $115(19)$ & $299(49)$ \\
\hline Tongue cleaner & $47(8)$ & $22(4)$ & $49(8)$ & $469(80)$ \\
\hline Irrigator & $17(3)$ & $10(2)$ & $18(3)$ & $536(92)$ \\
\hline Mouthwash & $165(25)$ & $120(18)$ & $159(24)$ & $219(33)$ \\
\hline
\end{tabular}

Data presented as number (percentage).

Table 5. Association of various factors with occurrence of gingival bleeding (only statistically significant correlation coefficients are shown)

\begin{tabular}{|l|c|}
\multicolumn{1}{|c|}{ Variable } & Correlation coefficient \\
\hline Age $[$ years] & -0.12 \\
Weight $[\mathrm{kg}]$ & -0.12 \\
$\mathrm{BMI}\left[\mathrm{kg} / \mathrm{m}^{2}\right.$ ] & -0.10 \\
Genetic susceptibility to periodontitis & 0.10 \\
Nicotinism [years] & -0.25 \\
Nicotinism [number of cigarettes per day] & -0.16 \\
Using mouthwash & 0.12 \\
Using manual toothbrush with soft bristles & 0.20 \\
\hline
\end{tabular}

$\mathrm{BMI}$ - body mass index. Data presented as number (percentage).

When asked about the last visit to the dentist, 14\% of the respondents answered that they had not been to the dental office in the last 2 years, while in the last year, there were almost $17 \%$ of the respondents visiting the dental office. The results concerning oral hygiene habits also turned out to be very disturbing. Although most of the respondents brushed teeth twice a day, as many as $16.9 \%$ that they brushed their teeth only once a day, and 3.5\% declared that they did not brush them at all. Statistical differences were in favor of women and residents of large cities, where only $0.9 \%$ never brushed their teeth. Individuals with higher education brushed teeth more often than those with basic education. In the accessory category, the subjects most frequently used manual brushes with soft or medium bristles. Sixty-eight percent of the respondents had never used an electric brush, 38\% did not use dental floss, and as many as 52\% had never used interdental brushes, which help maintain optimal mechanical plaque control in interproximal spaces. Thirty-three percent of the respondents did not use any mouthwash. Due to unlimited availability of a variety of oral hygiene products, selection of the most suitable ones for some patients may be problematic. Meanwhile, supragingival plaque should 
be removed mechanically by regularly applying a toothbrush, optimally twice a day, and cleaning the interdental spaces. Electric brushes with oscillating-rotating motion reduce the plaque by $7-57.9 \%$, gingival inflammation by $17-19.8 \%$ and bleeding of gingiva by $85.2 \%$ more effectively compared to manual brushes. ${ }^{9,10}$ The best results in reduction of plaque and gingivitis are demonstrated by electric toothbrushes with oscillating-rotating-pulsating action (working in a 3D system). ${ }^{2}$ Modern toothbrushes are characterized by 8,800 oscillating and 40,000 pulsating movements per minute. Electric toothbrushes do not pose a great threat to hard tissues of teeth and to gingiva, in relation to the occurrence of non-carious lesions and gingival recessions, compared to manual brushes. ${ }^{11}$

In order to remove plaque from interdental spaces, it is recommended to regularly use dental floss or interdental brushes. However, the effectiveness of dental floss in the removal of plaque from interdental spaces may be very low (15-19.4\%), depending on the patient's manual skills. ${ }^{12}$ Without proper instruction, its use does not reduce the occurrence of caries on interproximal surfaces of teeth. ${ }^{13}$ In patients with periodontitis, the use of toothbrushes results in better cleaning of interdental spaces than the use of dental floss alone. ${ }^{12,14}$ Vogel et al. showed that electric toothbrushes designed to clean interdental spaces are more effective than manual brushes, but their use is also associated with a higher risk of soft tissue damage, especially the gingival papilla. ${ }^{14}$ Therefore, it can be concluded that recommending the use of dental floss should be limited only to those interdental spaces that, due to their width, are not accessible for interdental brushes. ${ }^{15}$

Antiseptics may be helpful in controlling bacterial plaque, especially for individuals who have difficulty maintaining optimal oral hygiene with mechanical devices. ${ }^{16}$ The most effective compound used in mouthwash solutions is definitely chlorhexidine, which has anti-plaque (inhibits plaque development) and anti-inflammatory properties. ${ }^{17,18}$ It should not be used for more than 2 weeks due to local side effects (discoloration of teeth, fillings, prosthetic restorations, and mucosal membrane, as well as taste disorders and exfoliation of mucosal membrane epithelium). Such antiseptics also include plaque inhibitors that slow the growth of bacterial plaque: triclosan with a copolymer, essential oils, and aminofluorides in the form of toothpastes, gels and rinses. Regular use of mouthwashes containing fluorine compounds in childhood reduces the occurrence of carious lesions in permanent dentition. ${ }^{19}$ An effective, as far as plaque control and reduction of gingival inflammation are concerned, but at the same time the least popular antiseptic carrier is an aerosol..$^{20}$

On the basis of our research results, it can be stated that pro-health behaviors of Poles aimed at maintaining oral health are unsatisfactory. This was confirmed by epidemiological studies carried out on individuals aged $65-74$ years. ${ }^{7}$ As many as $78.3 \%$ of subjects regularly visited the dental office at least once a year. The most com- mon reason for the visit was pain (48.8\%). Only $25 \%$ of individuals were on regular control visits. A total of 5.7\% of respondents did not use a toothbrush every day, $18 \%$ brushed their teeth once a day, $50.2 \%$ twice a day, and $26 \%$ more often than twice a day. Only $17.22 \%$ of subjects regularly used dental floss.

Negligence in bacterial plaque control can cause gingivitis, manifested by bleeding while brushing teeth or eating hard foods. It should be remembered that gingival status assessment based on bleeding observed by patients is not reliable. Patients might not notice bleeding every time it occurs, especially if it concerns the posterior dentition or the lingual/palatal side of teeth, or when a slight inflammation of gingiva is present. The best way to verify inflammation is the dichotomous BoP (bleeding on probing) index according to Ainamo and Bay, which assesses the occurrence of gingival bleeding during careful probing of the bottom of the pocket on 4 surfaces of each tooth. ${ }^{21}$ The BoP value $<10 \%$ indicates no inflammation of the gums. In this study, bleeding from gums was reported by $50 \%$ of the respondents, including $5 \%$ of subjects with bleeding during every tooth brushing. A positive association of gum bleeding with genetic load, and with the use of a manual brush with soft bristles and mouthwash was observed. A soft bristle manual toothbrush may not be effective enough to control bacterial plaque, especially in the case of individuals with lower manual skills. On the other hand, the use of mouthwash as a substitute for tooth brushing also does not guarantee optimal plaque control, which can manifest itself in gingivitis. In the study group, the chance of gingival bleeding during tooth brushing decreased with age, weight, BMI, and nicotinism. The dynamics of inflammation in the oral cavity can diminish with age, especially in the cases of advanced periodontal diseases, which involve tooth extractions. Nicotinism is a risk factor for occurrence and development of periodontitis, but due to the vasoconstriction action of nicotine, clinical symptoms of gingivitis are less pronounced. It is difficult to explain the association observed between BMI and occurrence of gingival bleeding. Scientific studies have shown that the cumulative odds ratio (OR) for obesity and overweight, as a risk factor for periodontitis, was significant and equaled 2.13 (confidence interval - CI: $1.40-3.36 ; \mathrm{p}<0.001) .{ }^{22}$ With increased BMI, the risk of periodontitis also rises, and this relationship has a dose-effect nature. Perhaps the results of our study indicate a lower pro-health awareness of overweight individuals, who may overlook symptoms of gingivitis such as bleeding from gingiva. Moreover, these individuals might pay less attention to their oral health and, as a result, brush their teeth less frequently. However, this is actually a very debatable issue.

In long-term observations, hygienic habits that translate into bacterial plaque control may be reflected in the state of dentition and the number of retained teeth. The main cause of tooth loss in adult population is definite- 
ly caries. Less frequent causes are periodontal diseases, injuries, and orthodontic or prosthetic indications. Risk factors of early tooth loss, apart from medical ones, also include demographic, socio-economic and behavioral causes. Danish studies showed that regular dental care at school during childhood, the amount of personal income, education, and frequency of visits to the dental office constitute the most important factors affecting the preservation of own teeth. ${ }^{23}$ Some of these variables were evaluated in the present study. The number of lost teeth increased with age and the average number of teeth was 27 for the age group of 35-44 years. In the epidemiological study conducted by Górska et al. in 2012, the average number of teeth in this age group amounted to $26 .^{6}$ This data does not differ significantly from the average number of teeth in residents of other European Union countries. A similar number of teeth was found among the population of France - 27.1, lower in Germans and Danes - 25.1, and in Hungarians - 19.1..$^{22,24-26}$ A high dynamics of tooth loss in Poles is observed between 45 and 65 years of age. Our own questionnaire showed that over the age of 65 , the average number of teeth is 13 , similarly to the latest Polish epidemiological study. ${ }^{7}$ With reference to earlier studies, however, a clear trend of an increase in the average number of teeth in this age group can be observed. In the study by Jodkowska from 2009, the average number of teeth among Poles aged 65-74 years was only 6.6. ${ }^{27}$ The current situation is not significantly different compared to other European Union countries. Among Spaniards and the Swiss, the average number of teeth is 14.2 and 17.6, respectively, among Germans - 13.6; however, a lower number of teeth is found in Danes - 12.5 and Hungarians - 9.1..$^{25,26,28-30}$ Additionally, in our own study, the number of teeth did not differ significantly depending on sex, but was related to the place of residence. Inhabitants of large cities had a total of 23 teeth and residents of countryside villages - 22 teeth. Interestingly, the lowest number of teeth was observed among residents of medium-sized cities. ${ }^{19}$ However, it should be noted that village residents constituted only $12.3 \%$ of the respondents and it can be assumed that these results are subject to a considerable error. On the other hand, a clear trend was observed regarding an increase in the number of teeth present in the oral cavity depending on education. The respondents with higher education had on average 25 teeth compared to 13 teeth among respondents with primary education.

\section{Conclusions}

Pro-health behaviors of adult Poles in maintaining optimal oral hygiene are unsatisfactory. Women, young people living in big cities and those with higher education brush their teeth more often than men, older people living in the countryside, who received only primary education. For this purpose, manual brushes with medium and soft bristles are most commonly used, while additional instruments for interdental plaque control are implemented very rarely. This affects the state of gingiva. Inflammation, manifested by bleeding observed by the patients, occurs in $50 \%$ of the respondents. The average number of teeth does not differ significantly from that reported in epidemiological studies and remains associated with education.

\section{References}

1. Socransky SS, Haffajee AD. Dental biofilms: Difficult therapeutic targets. Periodontol 2000. 2002;28:12-55.

2. Mielczarek A, Banach J, Górska R. Comparison of effectiveness of manual and electric toothbrushes in elimination of dental plaque and gingivitis reduction. Dent Med Probl. 2013;50(4):467-471.

3. Sreenivasan PK, Prasad KVV. Distribution of dental plaque and gingivitis within dental arches. J Int Med Res. 2017;45(5):1585-1596.

4. Spivakovsky $S$, Keenan A. The effect of anti-plaque agents on gingivitis. Evid Based Dent. 2016;17(2):48-49.

5. Claydon NC. Current concepts in toothbrushing and interdental cleaning. Periodontol 2000. 2008;48:10-22.

6. Górska R, Pietruska M, Dembowska E, Wysokińska-Miszczuk J, Włosowicz M, Konopka T. Prevalence of periodontal diseases in 35-44 year-olds in the large urban agglomerations [in Polish]. Dent Med Probl. 2012;49(1):19-27.

7. Konopka T, Dembowska E, Pietruska M, Dymalski P, Górska R. Periodontal status and selected parameters of oral condition of Poles aged from 65 to 74 years. Przegl Epidemiol. 2015;69(3):537-542.

8. The evaluation of oral health and its determinants in Poles aged $35-44$ and 65-74. Epidemiological studies carried out in 2013 within the framework of health policy: "The monitoring of oral health of Polish population over the period 2013-2015", Ministry of Health, 2015.

9. Grender J, Williams K, Walters $P$, et al. Plaque removal efficacy of oscillating-rotating power toothbrushes: Review of six comparative clinical trials. Am J Dent. 2013;26(2):68-74.

10. Robinson PG, Deacon SA, Deery $C$, et al. Manual versus powered toothbrushing for oral health. Cochrane Database Syst Rev. 2005;18(2):CD002281.

11. Dörfer CE, Staehle HJ, Wolff D. Three-year randomized study of manual and power toothbrush effects on pre-existing gingival recession. J Clin Periodontol. 2016;43(6):512-519.

12. Blanck M, Mankodi S, Wesley P, Tasket R, Nelson B. Evaluation of the plaque removal efficacy of two commercially available dental floss devices. J Clin Dent. 2007;18(1):1-6.

13. Terézhalmy GT, Bartizek RD, Biesbrock AR. Plaque-removal efficacy of four types of dental floss. J Periodontol. 2008;79(2):245-250.

14. Vogel M, Sener B, Roos M, Attin T, Schmidlin PR. Interdental cleaning and gingival injury potential of interdental toothbrushes. Swiss Dent J. 2014;124(12):1290-1295.

15. Chapple IL, Van der Weijden F, Dörfer CE, et al. Primary prevention of periodontitis: Managing gingivitis. I Clin Periodontol. 2015;42(Suppl 16):S71-76.

16. Luís HS, Luís LS, Bernardo M, Santos NR. Randomized controlled trial on mouth rinse and flossing efficacy on interproximal gingivitis and dental plaque. Int J Dent Hyg. 2017;16(2):e73-e78.

17. Serrano J, Escribano M, Roldán S, Martín C, Herrera D. Efficacy of adjunctive anti-plaque chemical agents in managing gingivitis: A systematic review and meta-analysis. J Clin Periodontol. 2015;42 (Suppl 16):S106-138.

18. Reddy R, Palaparthy R, Durvasula S, et al. Gingivitis and plaque prevention using three commercially available dentifrices: A comparative clinical and microbiological randomized control parallel study. Int J Pharm Investig. 2017;7(3):111-118.

19. Marinho VC, Chong LY, Worthington HV, Walsh T. Fluoride mouthrinses for preventing dental caries in children and adolescents. Cochrane Database Syst Rev. 2016;7:CD002284.

20. Zhang J, Ab Malik N, McGrath C, Lam O. The effect of antiseptic oral sprays on dental plaque and gingival inflammation: A systematic review and meta-analysis. Int J Dent Hyg. 2018. doi: 10.1111/idh.12331 
21. Ainamo J, Bay I. Problems and proposals for recording gingivitis and plaque. Int Dent J. 1975;25(4):229-235.

22. Suvan J, D'Aiuto F, Moles DR, Petrie A, Donos N. Association between overweight/obesity and periodontitis in adults: A systematic review. Obes Rev. 2011;12(5):e381-404.

23. Petersen OE, Kjøller M, Christensen LB, Krustrup U. Changing dentate status of adults, use of dental health services, and achievement of National Dental Health Goals in Denmark by the year 2000. $J$ Public Health Dent. 2004;64(3):127-135.

24. Hescot P, Bourgeois D, Doury J. Oral health in 35-44-year-old adults in France. Int Dent J. 1997;47(2):94-99.

25. Holtfreter B, Kocher T, Hoffmann T, Desvarieux M, Micheelis W. Prevalence of periodontal disease and treatment demands based on a German dental survey (DMS IV). J Clin Periodontol. 2010;37(3):211-219.

26. Madléna $M$, Hermann $P$, Jáhn $M$, Fejérdy $P$. Caries prevalence and tooth loss in Hungarian adult population. BMC Public Health. 2008;8:364-364.

27. Jodkowska E. The condition of dentition status of adult Polish citizens in years 1998-2009 [in Polish]. Przegl Epidemiol. 2010;64(4):571-576.

28. Zitzmann NU, Staehelin K, Walls AW, Menghini G, Weiger R, Zemp Stutz E. Changes in oral health over a 10 -year period in Switzerland. Eur J Oral Sci. 2008;116(1):52-59.

29. Krustrup U, Petersen PE. Periodontal conditions in 35-44 and 65-74-year-old adults in Denmark. Acta Odont Scand. 2006;64(2):65-73.

30. König J, Hotfreter B, Kocher T. Periodontal health in Europe: Future trends based on treatment needs and the provision of periodontal services - position paper 1. Eur J Dent Educ. 2010;14(Suppl 1):4-24. 